\title{
PENGARUH KINERJA KEUANGAN DAN FAKTOR EKONOMI MAKRO DALAM MEMPREDIKSI VOLATILITAS HARGA SAHAM PERUSAHAAN SUBSEKTOR INDUSTRI FOOD AND BEVERAGES
}

\author{
Agung Fajar Ilmiyono \\ Fakultas Ekonomi Universitas Pakuan \\ E-mail: agung.fajar@unpak.ac.id
}

\begin{abstract}
This study aims to analyze and test the effect of financial performance and macro economic to stock price volatility in food and beverages companies listed in the Indonesia Stock Exchange period 2012-2016. Thirtyfive samples are tested by classical assumption using multiple regression analysis technique. The result shows that the financial performance partially has no significant effect on stock price volatility and macro economic partially has no significant effect on stock price volatility.
\end{abstract}

Keywords: ROA, DER, Net Cash Flow, Inflation, Exchange Rate, Interest Rate, and Volatility Stock Price

\section{ABSTRAK}

Penelitian ini bertujuan untuk menganalisis dan menguji pengaruh kinerja keuangan dan ekonomi makro terhadap volatilitas harga saham pada perusahaan food and beverages yang terdaftar di Bursa Efek Indonesia periode 2012-2016. Sebanyak 35 sampel data diuji dengan cara asumsi klasik menggunakan teknik analisis regresi berganda. Hasil penelitian menunjukkan bahwa kinerja keuangan secara parsial tidak berpengaruh signifikan terhadap volatilitas harga saham dan ekonomi makro secara parsial tidak berpengaruh signifikan terhadap volatilitas harga saham.

Kata Kunci: ROA, DER, Arus Kas Bersih, Inflasi, Nilai Tukar, Suku Bunga, dan Volatilitas Harga Saham

\section{PENDAHULUAN}

Pasar modal merupakan salah satu indikator penting dalam perekonomian suatu negara karena dapat memacu laju pertumbuhan ekonomi, membuat sektorsektor perekonomian menjadi lebih berkembang dan akan meningkatkan pendapatan suatu negara. Pasar modal di Indonesia mengalami perkembangan yang signifikan dari periode ke periode. Hal tersebut terbukti dengan meningkatnya jumlah transaksi saham yang kian tinggi. Sejalan dengan perkembangan yang pesat tersebut, kebutuhan akan informasi yang relevan dalam pengambilan keputusan investasi di pasar modal juga semakin meningkat.

Volatilitas harga saham dipengaruhi oleh banyak faktor. Faktor-faktor ini dikategorikan dalam 2 kelompok, yaitu faktor mikro dan makro perusahaan. Faktor mikro meliputi pertumbuhan aset, pertumbuhan laba, arus kas, ROE, pengungkapan sukarela, pengungkapan informasi, dividen dan pertumbuhan perusahaan. Sedangkan faktor makro meliputi inflasi, suku bunga dan nilai tukar.

Sementara itu analisis yang populer digunakan untuk menganalisis saham ada dua, yaitu analisis teknikal dan analisis fundamental. Analisis teknikal adalah metode

JIAFE (Jurnal Ilmiah Akuntansi Fakultas Ekonomi)

Volume 3 No. 1 Tahun 2017, Hal. 35-48 
yang digunakan oleh analis untuk mengevaluasi saham yang berdasarkan pada data-data statistik yang dihasilkan dari aktivitas perdagangan saham, seperti harga saham dan volume transaksi. Sedangkan analisis fundamental mempelajari atau mengamati berbagai indikator yang terkait dengan kondisi makro ekonomi dan kondisi industri suatu perusahaan hingga berbagai indikator keuangan dan manajemen perusahaan (Darmadji dan Fakhrudin, 2012:149). Penelitian ini fokus pada analisis fundamental sebagai alat penilaian suatu saham.

Analisis fundamental secara top-down dapat digunakan investor untuk menilai prospek suatu perusahaan (Tandelilin, 2010:338). Analisis terhadap faktor-faktor makro ekonomi yang mempengaruhi kinerja seluruh perusahaan adalah langkah pertama yang dilakukan, selanjutnya adalah melakukan analisis industri, dan terakhir melakukan analisis terhadap perusahaan yang mengeluarkan sekuritas untuk menilai apakah sekuritas tersebut mampu memberikan keuntungan bagi investor atau tidak.

Produk Domestik Bruto (PDB), inflasi, tingkat pengangguran, tingkat suku bunga, dan nilai tukar adalah beberapa variabel makro ekonomi yang sering diperhatikan. Inflasi, tingkat suku bunga, dan nilai tukar mata uang merupakan variabel yang akan digunakan dalam penelitian ini, temasuk risiko investasi sistematis yaitu risiko yang akan terjadi secara konstan dan tidak dapat dihindari sehingga hanya dapat diturunkan risikonya dengan cara menunda pembelian, menahan saham dalam jangka waktu yang lama atau meninggalkan pasar sementara karena dengan fluktuatifnya faktor-faktor tersebut akan berdampak juga dengan nilai saham dari suatu perusahaan

Ika Yunita dan Al Amin (2016) dalam penelitiannya menyatakan Return On Assets (ROA) berpengaruh signifikan terhadap harga saham sedangkan inflasi tidak berpengaruh terhadap harga saham. Kemudian Kewal (2012) dalam penelitiannya menyatakan bahwa hanya kurs yang berpengaruh secara signifikan terhadap IHSG, sedangkan tingkat inflasi, suku bunga SBI dan pertumbuhan PDB tidak berpengaruh terhadap IHSG.

Berbeda dengan penelitian di atas, penelitian yang dilakukan oleh Atin (2015) menunjukkan bahwa ROE, EPS, tingkat bunga, tingkat inflasi, dan tingkat nilai tukar rupiah berpengaruh terhadap harga saham. Senada dengan Atin (2015), Hykaj (2015), dalam penelitiannya menyatakan bahwa inflasi berpengaruh signifikan terhadap harga saham. Begitu pula dengan Kurniawati \& Rizki (2014) yang menyatakan bahwa pertumbuhan laba berpengaruh terhadap harga saham.

Penelitian Paul et al. (2014) di Fiji Islands menemukan terdapat dua faktor eksternal yang sangat berpengaruh terhadap harga saham yaitu inflasi dan nilai tukar. Hal senada dikemukakan juga oleh Kabir et al (2014) bahwa di Malaysia harga saham dipengaruhi oleh inflasi, suku bunga serta nilai tukar. Kemudian dari penelitiannya, Sihaloho (2013) memperoleh hasil bahwa inflasi berpengaruh negatif signifikan terhadap harga saham. Jika inflasi meningkat maka harga saham akan menurun, begitu pula sebaliknya. Kemudian pada suku bunga diperoleh hasil bahwa suku bunga berpengaruh negatif signifikan terhadap harga saham. Jika suku bunga meningkat maka harga saham akan menurun pula, begitupun sebaliknya. Kandir (2008), memperkuat penemuan tersebut yaitu inflasi berpengaruh terhadap pergerakan harga saham. Penemuan serupa juga dikemukakan oleh penelitian-penelitian lain seperti Ang dan Maddaloni (2005): inflasi, suku bunga dan nilai tukar berpengaruh terhadap harga saham; dan Permana (2009): fundamental, suku bunga, inflasi mempunyai pengaruh secara signifikan terhadap perubahan harga saham perusahaan sedangkan secara parsial 
hanya variabel PBV mempunyai pengaruh secara signifikan.

Disamping faktor-faktor tersebut di atas harga saham dipengaruhi juga oleh faktor lain. Abbas et al. (2013) dalam penelitian yang dilakukan di Pakistan menyimpulkan dividen tidak mempengaruhi harga saham hanya pertumbuhan laba dan ROE yang berpengaruh. Deitiana (2011) menyatakan dividen dan pertumbuhan penjualan tidak berpengaruh pada harga saham. Sementara Rinati (2010) menunjukkan variabel ROE dan pertumbuhan laba tidak berpengaruh signifikan, hanya pertumbuhan aset yang memiliki pengaruh signifikan. Timbul et al. (2009) berpendapat hal yang sama terhadap penelitian Rinati bahwa ROE tidak berpengaruh terhadap harga saham, namun Timbul et al. menyimpulkan bahwa pertumbuhan laba dan pertumbuhan aset berpengaruh signifikan. Hal yang berbeda mengenai ROE namun senada dengan penelitian dari Abbas et al. (2013) dikemukakan oleh Kusumajaya (2011) yaitu bahwasannya ROE berpengaruh terhadap harga saham, begitu juga dengan pertumbuhan laba dan aset.

Adapun identifikasi masalah dalam penelitian ini adalah laju inflasi yang tinggi akan mendorong kenaikan harga bahan baku dan meningkatkan berbagai biaya operasi perusahaan, menyebabkan harga jual barang meningkat dan menurunkan daya beli masyarakat. Hal ini berdampak pada turunnya penjualan perusahaan, sehingga keuntungan dan kinerja keuangan perusahaan mengalami penurunan. Pada tingkat suku bunga yang tinggi tentu sangat memberatkan operasi perusahaan yang ingin melakukan investasi baru, terutama bagi perusahaan yang memiliki rasio pinjaman yang tinggi, karena terancam tidak mampu melunasi hutang-hutangnya, sehingga berdampak pada turunnya kinerja keuangan perusahaan. Sementara itu pertumbuhan perusahaan juga merupakan salah satu indikator keberhasilan perusahaan dalam mempertahankan

keberlangsungan operasional perusahaan, yang dapat tercermin dari pertumbuhan aset dan pertumbuhan laba perusahaan.

Sektor perusahaan manufaktur merupakan salah satu bagian dari sektor industri di pasar modal. Di sektor ini terdapat beberapa macam subsektor, salah satunya adalah subsektor perusahaan food and beverages yang digunakan sebagai sampel dalam penelitian ini. Food and beverages dipilih karena memegang peranan penting dalam memenuhi kebutuhan masyarakat. Perusahaan makanan dan minuman ini akan terus ada dan relatif stabil terhadap krisis dibandingkan dengan sektor lainnya. Dalam kondisi krisis atau tidak, produk makanan dan minuman tetap dibutuhkan. Bahkan dalam keadaan krisis, konsumen akan membatasi konsumsinya dengan memenuhi kebutuhan dasar terhadap makanan dan minuman, dan mengurangi kebutuhan barang sekunder.

Oleh karena itu, penelitian ini bermaksud untuk menilai sejauh mana pengaruh pergerakan faktor kinerja keuangan dan ekonomi makro dalam memprediksi volatilitas harga saham perusahaan di sektor food and beverages.

\section{KAJIAN LITERATUR \\ Teori Signalling}

Teori signalling (Ross, 1977) menyatakan bahwa eksekutif perusahaan yang memiliki informasi lebih baik mengenai perusahaannya akan terdorong untuk menyampaikan informasi tersebut kepada calon investor agar harga sahamnya meningkat. Signalling theory mendasarkan pada asumsi bahwa informasi yang diterima oleh masing-masing pihak tidak sama. Dengan kata lain, terdapat asimetri informasi antara manajemen perusahaan dengan pihak-pihak yang berkepentingan dengan informasi. 


\section{ROA, DER, Arus Kas Bersih, Inflasi, Suku Bunga, dan Nilai Tukar}

Menurut Kasmir (2013:196) rasio profitabilitas merupakan rasio untuk menilai kemampuan perusahaan dalam mencari keuntungan. Rasio ini juga memberikan ukuran tingkat efektivitas manajemen suatu perusahaan dan menunjukkan efisiensi perusahaan.

Solvabilitas merupakan kemampuan suatu perusahaan untuk membayar semua hutangnya baik jangka pendek maupun jangka panjang (Kartika, 2011:6). Rasio ini menunjukan persentase penyediaan dana oleh pemegang saham terhadap pemberi pinjaman. Semakin tinggi rasio ini, semakin rendah pendanaan perusahaan yang disediakan oleh pemegang saham.

Menurut Skousen dkk (2009:284) laporan arus kas itu sendiri didefinisikan sebagai laporan keuangan yang melaporkan jumlah kas yang diterima dan dibayar oleh suatu perusahaan selama periode tertentu. Darmadji dan Fakhruddin (2006:116) mendefinisikan inflasi sebagai suatu kondisi dimana harga barang-barang pada umumnya menjadi lebih tinggi dari sebelumnya. Pada hakekatnya inflasi yang tinggi dapat memberikan dampak yang negatif ketika kenaikan harga jual produk perusahaan akibat naiknya biaya produksi tidak dapat diserap oleh pasar. Atau apabila peningkatan biaya produksi lebih tinggi dibandingkan peningkatan harga jual produk perusahaan maka hal ini akan mempengaruhi tingkat margin yang akan diperoleh perusahaan. Inflasi yang berkaitan dengan pasar modal adalah investasi yang berasal dari sektor moneter. Hal ini karena inflasi berkaitan langsung dengan tingkat suku bunga di pasar.

Suku bunga adalah biaya pinjaman atau harga yang dibayarkan untuk dana pinjaman tersebut (Miskhin, 2008:4). Sedangkan menurut Sunariyah (2011) tingkat suku bunga adalah tingkat keuntungan yang di dapat oleh investor atas investasi yang ditanamkan atau merupakan biaya yang harus keluarkan oleh perusahaan untuk menggunakan dana investor tersebut. Suku bunga ini penting untuk diperhitungkan karena rata-rata para investor yang selalu mengharapkan hasil investasi yang lebih besar. Dengan adanya perubahan suku bunga, tingkat pengembalian hasil berbagai sarana investasi akan mengalami perubahan.

Keown (2010:373) mengatakan bahwa nilai tukar (exchange rate) adalah harga mata uang asing yang dinyatakan ke dalam mata uang negara asal atau jumlah uang domestik yang dibutuhkan untuk satu unit mata uang asing (Murni dalam Nuraeni 2011:38).

\section{Volatilitas Harga Saham}

Pergerakan naik atau turunnya harga saham di bursa efek merupakan volatilitas harga saham. Untuk mengukur risiko dari suatu saham dapat dilihat dari volatilitas harga saham tersebut. Volatilitas yang lebih besar menunjukkan kemungkinan terjadinya keuntungan atau kerugian yang lebih tinggi dalam jangka pendek. Harga dari saham yang mempunyai volatilitas tinggi dapat berubah sewaktu-waktu dan perubahannya sulit untuk diprediksi. Nilai volatilitas yang tinggi menunjukkan bahwa harga saham berubah (naik dan turun) dengan range yang sangat lebar. Sedangkan volatilitas dikatakan rendah jika harga saham jarang berubah atau cenderung konstan.

\section{PENGEMBANGAN HIPOTESIS}

Semakin besar ROA perusahaan, semakin besar pula tingkat keuntungan yang dicapai oleh perusahaan tersebut. Semakin tinggi keuntungan perusahaan akan membuat investor tertarik untuk membel saham perusahaan tersebut sehingga harga saham perusahaan tersebut akan naik. Penelitian yang dilakukan oleh Ika Yunita dan Al Amin (2016) menunjukkan bahwa ROA berpengaruh signifikan terhadap harga saham. Maka kesimpulan hipotesis dalam penelitian ini adalah sebagai berikut: 
$\mathbf{H}_{1}$ : Tidak terdapat hubungan yang signifikan antara ROA terhadap volatilitas harga saham pada perusahaan manufaktur subsektor food and beverages yang terdaftar di BEI.

Debt to Equity Ratio (DER) memperlihatkan perbandingan antara total hutang dengan modal yang dimiliki perusahaan. Semakin tinggi hutang yang dimiliki perusahaan akan memiliki probabilitas untuk mengalami kesulitan dalam memenuhi kewajiban tersebut dan mencerminkan risiko yang tinggi bagi perusahaan. Perusahaan yang memiliki nilai DER yang tinggi membuat investor tidak tertarik untuk berinvestasi karena mencerminkan tingkat risiko perusahaan yang tinggi. Hasil penelitian yang dilakukan oleh Sofi dan Yahya (2016) menyatakan bahwa variabel DER tidak berpengaruh signifikan terhadap harga saham. Maka rumusan hipotesis kedua dalam penelitian ini adalah sebagai berikut:

$\mathbf{H}_{2}$ : Tidak terdapat hubungan yang signifikan antara DER terhadap volatilitas harga saham pada perusahaan manufaktur subsektor food and beverages yang terdaftar di BEI.

Menurut Tendelilin (2010:324), data aliran kas perusahaan bisa memberikan pemahaman lebih mendalam bagi investor tentang perubahan harga saham yang terjadi. Dari pemaparan di atas, dengan kata lain dapat dilihat bahwa semakin meningkat arus kas, maka semakin meningkat pula harga saham di perusahaan tersebut. Sebaliknya jika arus kas mengalami penurunan maka harga saham perusahaan tersebut juga akan mengalami penurunan. Hal ini sejalan dengan penelitian yang dilakukan oleh Asrianti dan Syamsuri (2015) terhadap perusahaan LQ45 di Bursa Efek Indonesia, yang menunjukkan bahwa variabel arus kas berpengaruh signifikan tehadap harga saham. Maka rumusan hipotesis ketiga dalam penelitian ini adalah sebagai berikut:
$\mathbf{H}_{3}$ : Tidak terdapat hubungan yang signifikan antara AKB terhadap volatilitas harga saham pada perusahaan manufaktur subsektor food and beverages yang terdaftar di BEI.

Mankiw (2012:141-142) menjelaskan bahwa inflasi adalah kenaikan tingkat harga secara keseluruhan. Tingkat inflasi diukur sebagai persentase perubahan dalam Indeks Harga Konsumen (IHK), deflator PDB, atau indeks-indeks lain dalam harga keseluruhan. Inflasi dipengaruhi oleh jumlah uang.

$\mathbf{H}_{4}$ : Tidak terdapat hubungan yang signifikan antara inflasi terhadap volatilitas harga saham pada perusahaan manufaktur subsektor food and beverages yang terdaftar di BEl.

Penelitian yang dilakukan oleh Atin (2015) menyatakan bahwa variabel nilai tukar berpengaruh signifikan terhadap harga saham. Berdasarkan pemaparan tentang nilai tukar di atas maka rumusan hipotesis selanjutnya dalam penelitian ini adalah sebagai berikut:

$\mathbf{H}_{5}$ : Terdapat hubungan yang signifikan antara nilai tukar terhadap volatilitas harga saham pada perusahaan manufaktur subsektor food and beverages yang terdaftar di BEI.

Penelitian yang dilakukan oleh Edhi Asmirantho dkk (2016) menemukan bahwa variabel $C R, D E R, E P S, R O A, E V A, P E R$, dan SBI berpengaruh signifikan terhadap harga saham. Sedangkan IT dan inflasi tidak berpengaruh terhadap harga saham. Sehingga rumusan hipotesis keenam dalam penelitian ini adalah sebagai berikut:

$\mathbf{H}_{6}$ : Tidak terdapat hubungan yang signifikan antara suku bunga terhadap volatilitas harga saham pada perusahaan manufaktur subsektor food and beverages yang terdaftar di BEl.

\section{METODOLOGI PENELITIAN}

Sampel yang dipilih menggunakan metode purposive sampling yaitu sampel

JIAFE (Jurnal Ilmiah Akuntansi Fakultas Ekonomi)

Volume 3 No. 1 Tahun 2017, Hal. 35-48 
dipilih dengan menggunakan pertimbangan tertentu disesuaikan dengan tujuan penelitian atau masalah penelitian yang dikembangkan. Sampel yang digunakan dalam penelitian ini adalah perusahaan manufaktur makanan dan minuman yang terdaftar di Bursa Efek Indonesia, menerbitkan laporan tahunan lengkap baik annual report maupun laporan keuangan tahun 2012-2016, memiliki nilai pertumbuhan aset yang positif dan tidak pernah mengalami kerugian selama periode penelitian tahun 2012-2016.
Data yang digunakan adalah data sekunder yang merupakan data laporan keuangan, dan harga saham yang dijadikan sampel tersedia di halaman website Bursa Efek Indonesia (www.idx.co.id), Yahoo Finance (www.finance.yahoo.com), www.bi.go.id dan www.bps.go.id.

Dalam penelitian ini yang menjadi variabel independen adalah ROA, DER, arus kas bersih, inflasi, nilai tukar dan suku bunga sedangkan variabel dependennya adalah volatilitas harga saham.

Tabel 1. Operasionalisasi Variabel

\begin{tabular}{|c|c|c|c|c|}
\hline Variabel & Sub Variabel & Ukuran & Skala & Rujukan \\
\hline \multirow{4}{*}{$\begin{array}{l}\text { Kinerja } \\
\text { Keuangan }\end{array}$} & & Net Income $\times 100 \%$ & \multirow{4}{*}{ Rasio } & \multirow{4}{*}{$\begin{array}{l}\text { Kusumajaya (2011), } \\
\text { Permana (2009), } \\
\text { Timbul et al. (2009) }\end{array}$} \\
\hline & ROA & Total Aset & & \\
\hline & DER & $\frac{\text { Total Kewajiban }}{\text { Total Ekuitas }} \times 100 \%$ & & \\
\hline & Arus Kas Bersih & PAKit $=($ AKit - AKit-1 $)$ & & \\
\hline \multirow{4}{*}{$\begin{array}{l}\text { Faktor } \\
\text { Ekonomi } \\
\text { Makro }\end{array}$} & Inflasi & Harga Sekarang $\quad$ x $100 \%$ & \multirow{4}{*}{ Rasio } & \multirow{4}{*}{$\begin{array}{ll}\text { Kabir et al. } & \text { (2014), } \\
\text { Sihaloho } & (2013), \\
\text { Permana } & (2009), \\
\text { Ang et al. } & (2005)\end{array}$} \\
\hline & & Kurs Jual + Kurs Beli & & \\
\hline & Nilai Tukar & 2 & & \\
\hline & $\begin{array}{l}\text { Suku Bunga } \\
\text { Indonesia }\end{array}$ & Rata-rata BI RATE Selama 1 Tahun & & \\
\hline $\begin{array}{l}\text { Harga } \\
\text { Saham }\end{array}$ & $\begin{array}{l}\text { Harga Penutupan } \\
\text { Saham (Closing } \\
\text { Price) }\end{array}$ & $\begin{array}{l}\text { Rata-rata (mean) harga saham } \\
\text { selama periode tahun 2011-2015 }\end{array}$ & Rasio & $\begin{array}{l}\text { Kabir et al. }(2014), \\
\text { Sihaloho } \\
\text { Kusumajaya } \\
\text { (2013), } \\
\text { Permana } \\
\text { Timbul et al. (2009), } \\
\text { Ang et al. (2005), }\end{array}$ \\
\hline $\begin{array}{l}\text { Volatilitas } \\
\text { Harga } \\
\text { Saham }\end{array}$ & $\begin{array}{l}\text { Harga Penutupan } \\
\text { Saham (Closing } \\
\text { Price) }\end{array}$ & $\begin{array}{l}\text { Rata-rata (mean) harga saham } \\
\text { (Standard Error ) selama periode } \\
\text { tahun 2011-2015 }\end{array}$ & Rasio & $\begin{array}{l}\text { Hykaj (2015), } \\
\text { Napitupulu et al. } \\
\text { (2013), Hugida dan } \\
\text { Sofian (2011), } \\
\text { Anton (2006), Jones } \\
\text { et al. (1994) }\end{array}$ \\
\hline
\end{tabular}




\section{PENGUJIAN HIPOTESIS}

Pengaruh ROA Terhadap Volatilitas Harga Saham

Hipotesis yang pertama adalah ROA tidak berpengaruh terhadap volatilitas harga saham. Nilai ROA pada uji t 1,800 yang artinya pada variabel ROA tidak berpengaruh terhadap volatilitas harga saham pada perusahaan manufaktur subsektor food and beverages yang terdaftar di Bursa Efek Indonesia pada tahun 2012-2016.

\section{Pengaruh DER terhadap Volatilitas Harga Saham}

Hipotesis yang kedua menyatakan bahwa DER tidak berpengaruh terhadap volatilitas harga saham pada perusahaan food and beverages yang terdaftar di BEI. Untuk membuktikan hipotesis tersebut maka mengacu nilai DER pada uji t 0,094 yang artinya pada variabel DER tidak berpengaruh terhadap volatilitas harga saham pada perusahaan manufaktur subsektor food and beverages yang terdaftar di Bursa Efek Indonesia pada tahun 2012-2016, hasil ini dibuktikan dengan nilai signifikansi lebih besar dari $5 \%(0,094>0,05)$.

\section{Pengaruh Arus Kas Bersih terhadap Volatilitas Harga Saham}

Hipotesis yang ketiga menyatakan bahwa arus kas bersih tidak berpengaruh terhadap volatilitas harga saham pada perusahaan food and beverages yang terdaftar di BEl. Oleh karena itu, untuk membuktikan pernyataan hipotesis tersebut maka dapat mengacu kepada hasil pengujian nilai AKB pada uji t 0,490 yang artinya pada variabel AKB tidak berpengaruh terhadap harga saham pada perusahaan manufaktur subsektor food and beverages yang terdaftar di Bursa Efek Indonesia pada tahun 20122016, hasil ini dibuktikan dengan nilai signifikansi lebih besar dari $5 \%(0,490<0,05)$.

Pengaruh Inflasi terhadap Volatilitas Harga Saham
Hipotesis keempat menyatakan bahwa Inflasi tidak berpengaruh terhadap volatilitas harga saham pada perusahaan food and beverages yang terdaftar di BEI. Untuk membuktikan hipotesis tersebut maka dapat mengacu kepada hasil pengujian nilai inflasi pada uji t 0.669 yang artinya pada variabel inflasi tidak berpengaruh terhadap harga saham pada perusahaan manufaktur subsektor food and beverages yang terdaftar di Bursa Efek Indonesia pada tahun 20122016, hasil ini dibuktikan dengan nilai signifikansi lebih besar dari 5\% $(0,669>0,05)$.

\section{Pengaruh Nilai Tukar terhadap Volatilitas Harga Saham}

Hipotesis kelima menyatakan bahwa nilai tukar berpengaruh terhadap volatilitas harga saham pada perusahaan food and beverages yang terdaftar di BEI. Untuk membuktikan hipotesis tersebut maka dapat mengacu kepada hasil pengujian nilai tukar pada uji t 0,673 yang artinya pada variabel nilai tukar tidak berpengaruh terhadap harga saham pada perusahaan manufaktur subsektor food and beverages yang terdaftar di Bursa Efek Indonesia pada tahun 20122016, hasil ini dibuktikan dengan nilai signifikansi lebih besar dari 5\% $(0,673>0,05)$.

\section{Pengaruh Suku Bunga Terhadap Volatilitas Harga Saham}

Hipotesis keenam menyatakan bahwa suku bunga tidak berpengaruh terhadap volatilitas harga saham pada perusahaan food and beverages yang terdaftar di BEl. Untuk membuktikan hipotesis tersebut maka dapat mengacu kepada hasil pengujian nilai suku bunga pada uji t -0,368 yang artinya pada variabel suku bunga tidak berpengaruh terhadap harga saham pada perusahaan manufaktur subsektor food and beverages yang terdaftar di Bursa Efek Indonesia pada tahun 2012-2016, hasil ini dibuktikan dengan nilai signifikansi lebih besar dari 5\% (-0,368 > $0,05)$. 


\section{PEMBAHASAN}

\section{Pengaruh ROA terhadap Volatilitas Harga} Saham

Secara teori dan penelitian sebelumnya, variabel ROA naik maka variabel harga saham akan naik dan sebaliknya, jika variabel ROA turun maka variabel harga saham akan turun. Kondisi ini menunjukan bahwa semakin besar tingkat ROA maka semakin baik tingkat efisiensi suatu perusahaan dalam memperoleh laba dengan memanfaatkan aktiva yang dimilikinya. Sehingga ROA dapat dijadikan salah satu pertimbangan investor dalam memilih saham perusahaan. Berdasarkan hasil penelitian yang telah dilakukan, ROA secara parsial tidak memiliki pengaruh yang signifikan terhadap volatilitas harga saham. Hal ini berbanding terbalik dengan penelitian yang dilakukan oleh Ika Yunita dan Al Amin (2016) yang menyatakan bahwa ROA berpengaruh signifikan terhadap harga saham.

\section{Pengaruh DER terhadap Volatilitas Harga Saham}

Berdasarkan hasil penelitian yang telah dilakukan, DER secara parsial tidak berpengaruh terhadap volatilitas harga saham. Hal ini berarti jika variabel DER naik maka variabel harga saham akan naik dan sebaliknya, jika variabel DER turun maka variabel harga saham akan turun. Kondisi ini menunjukan bahwa semakin besar tingkat DER maka semakin rendah pendanaan perusahaan yang disediakan oleh pemegang saham. Hasil dari penelitian ini DER tidak berpengaruh terhadap harga saham. Hal ini sesuai dengan penelitian yang dilakukan oleh Sofi dan Yahya (2016) bahwa variabel DER tidak berpengaruh signifikan terhadap harga saham.

\section{Pengaruh Arus Kas Bersih terhadap Volatilitas Harga Saham}

Berdasarkan hasil penelitian yang telah dilakukan, arus kas bersih secara parsial tidak berpengaruh terhadap volatilitas harga saham. Hal ini berarti jika variabel AKB naik maka variabel harga saham akan naik dan sebaliknya, jika variabel AKB turun maka variabel harga saham akan turun. Kondisi ini menunjukan bahwa semakin besar tingkat AKB maka semakin baik tingkat efektifitas suatu perusahaan dalam memperoleh pendaaan dari dalam perusahaan tanpa mengandalkan sumber pendanaan dari luar perusahaan. Hasil dari penelitian ini AKB memiliki pengaruh yang signifikan terhadap harga saham. Hal ini berbeda dengan penelitian yang dilakukan oleh Asrianti dan Syamsuri (2015) bahwa variabel arus kas berpengaruh signifikan tehadap harga saham.

\section{Pengaruh Inflasi terhadap Volatilitas Harga Saham}

Inflasi tidak berpengaruh terhadap volatilitas harga saham. Hal ini jelas menggambarkan bahwa laju inflasi yang tinggi akan mendorong kenaikan harga bahan baku dan meningkatkan berbagai biaya operasi perusahaan, menyebabkan harga jual per unit barang meningkat dan menurunkan daya beli masyarakat. Hal ini berdampak pada turunnya penjualan perusahaan, sehingga keuntungan dan kinerja keuangan perusahaan mengalami penurunan, yang pada akhirnya investor akan ragu untuk membeli saham perusahaan tersebut, hal ini menandakan volatilitas harga sahamnya rendah. Hasil penelitian ini tidak konsisten dengan penelitian dalam dan luar negeri, dari dalam negeri hasil penelitian yang sejalan dari peneliti sebelumnya yaitu Sihaloho (2013), Permana (2009), dan Kandir (2008) yang menunjukkan bahwa inflasi mempunyai pengaruh negatif signifikan terhadap harga saham. Begitu juga penelitian Thobarry (2009) yang menyatakan bahwa pengaruh negatif tingkat inflasi terhadap indeks harga saham sektor properti di BEI pada tahun 2000-2008. Sementara penelitian dari luar negeri yang tidak konsisten dengan penelitian ini adalah Paul, et al. (2014), Kabir, et al. (2014), Ang, et al (2005,. Sedangkan penelitian Kewal, (2012) konsisten dengan 
penelitian ini, mereka mengatakan bahwa inflasi tidak berpengaruh signifikan terhadap pergerakan harga saham. Dari hasil penelitian yang tidak konsisten ini sejalan dalam literatur Tandelilin (2010, 343) yaitu peningkatan inflasi secara relatif merupakan sinyal negatif bagi pemodal di pasar modal.

\section{Pengaruh Nilai Tukar terhadap Volatilitas Harga Saham}

Berdasarkan hasil penelitian yang telah dilakukan, nilai tukar secara parsial tidak berpengaruh terhadap volatilitas harga saham. Hal ini berarti jika variabel nilai tukar naik maka variabel harga saham akan naik dan sebaliknya, jika variabel nilai tukar turun maka variabel harga saham akan turun. Kondisi berarti semakin tinggi harga saham akan menyebabkan semakin tinggi permintaan uang dengan tingkat bunga yang semakin tinggi pula, sehingga hal ini akan menarik minat investor asing untuk menanamkan modalnya. Hasil penelitian ini berbeda dengan penelitian yang dilakukan oleh Atin (2015) bahwa variabel nilai tukar berpengaruh signifikan terhadap harga saham.

\section{Pengaruh Suku Bunga terhadap Volatilitas Harga Saham}

Suku bunga tidak berpengaruh terhadap volatilitas harga saham pada perusahaan food and beverages yang terdaftar di BEI. Dengan hal seperti itu maka dapat disimpulkan bahwa suku bunga secara parsial tidak berpengaruh terhadap volatilitas harga saham. Hanya Kewal, (2012) konsisten dengan penelitian ini, sementara hasil dari penelitian lain tidak konsisten dengan penelitian sebelumnya yaitu Sihaloho, (2013), Permana (2009), sementara Hykay, (2015), Kabir, et al. (2014), Ang, et al. (2005), Granger, et.al (1998) konsisten dengan hasil penelitian ini. Penelitian Watanapalachaikul (2003) menyatakan bahwasanya suku bunga berpengaruh terhadap pergerakan harga saham, disamping faktor ekonomi lainnya yang dikaji seperti nilai tukar, harga pasar, harga pangan, EPR, dan CPI yang diteliti di negara Thailand pada tahun 1992-2001. Sejalan dengan teori yang disampaikan oleh Bodie and Marcus, 2006 bahwa bagi perusahaan, tingkat bunga yang tinggi mengurangi nilai sekarang dari arus kas masa depan, sehingga mengurangi daya tarik peluang sebuah investasi yang pada akhirnya investor akan menanamkan dananya pada saham yang secara langsung akan menaikkan volatilitas harga saham. Tingkat bunga yang rendah akan mendorong laju investasi dan konsumsi, sehingga karena ini tingkat bunga riil menjadi penentu kunci dari pengeluaran investasi bisnis.

\section{SIMPULAN}

Dari hasil penelitian yang dilakukan pada bab sebelumnya, dapat ditarik beberapa kesimpulan bahwa ROA, DER, dan AKB secara parsial tidak berpengaruh terhadap volatilitas harga saham dengan nilai signifikansi lebih kecil dari 0,05 (5\%). Begitu juga variabel makro ekonomi berupa inflasi, nilai tukar, dan suku bunga secara parsial tidak berpengaruh terhadap volatilitas harga saham dengan nilai signifikansi lebih besar dari 0,05 (5\%).

Penelitian ini hanya mengambil populasi dan sampel pada perusahaanperusahaan food and beverages di Bursa Efek Indonesia pada periode tahun 2012 sampai tahun 2016. Dengan pendeknya periode penelitian dan jumlah data yang terbatas tersebut, maka hasilnya pun terlihat kurang optimal. Kemudian hasil penelitian tidak dapat menggambarkan situasi secara keseluruhan. Hal tersebut disebabkan jumlah perusahaan food and fbverages yang terdaftar di Bursa Efek Indonesia pada periode penelitian jumlahnya sedikit. Selain dari pada itu, variabel yang digunakan dalam penelitian ini hanya mengggunakan tiga variabel dari faktor internal dan eksternal perusahaan saja.

Oleh karena itu, untuk penelitian selanjutnya akademisi dalam melihat 
pengaruh faktor ekonomi makro dapat dilakukan dengan meregres terlebih dahulu data yang akan dilihat nilai sensitivitasnya, begitupun halnya dengan nilai volatilitas harga saham harus diregres terlebih dahulu. Para peneliti juga dapat lebih lanjut meneliti pengaruh makro dan mikro ekonomi terhadap volatilitas harga saham di sektor industri lainnya sehingga dapat dipilih indeks harga saham sektor mana saja yang tahan terhadap kondisi makro dan mikro ekonomi yang tidak stabil dan sektor mana saja yang rentan terhadap tidak stabilnya kondisi makro dan mikro ekonomi, seperti misalnya proksi nilai tukar, kebijakan pemerintah dan kondisi ekonomi, sedangkan dari faktor mikro dapat dikaji arus kas perusahaan, pengungkapan informasi dan pertumbuhan penjualan. Sementara untuk praktisi khususnya di sektor industri food and beverages bahwa faktor eksternal ternyata lebih besar berpengaruh terhadap banyaknya investasi yang akan ditanamkan pada sekuritas dipasar modal, dibanding faktor internal perusahaan. Hal ini dapat terjadi karena faktor internal dapat dikontrol oleh perusahaan dibandingkan faktor eksternal yang sulit untuk diprediksi keterjadiannya. Sehingga, dalam hal akan berinvestasi faktor eksternal harus lebih banyak dikaji dan mendapat perhatian.

\section{DAFTAR PUSTAKA}

Ang and Maddaloni. 2005. Frequently Used Variables Are GDP Growth Rate, Industrial Production Rate, ShortTerm Interest Rate, Inflation Rate, Interest Rate Spread, Exchange Rate, Current Account Balance, Unemployment Rate, Fiscal Balance, Etc. Journal of Business Research.

Anton, A. 2006. Analisis Model Volatilitas Return Saham (Studi Kasus pada Saham LQ 45 di Bursa Efek Jakarta). Tesis, Program Pascasarjana Universitas Diponegoro.
Atin (2015), Pengaruh ROE, EPS, Tingkat Bunga, Tingkat Inflasi, dan Nilai Tukar Rupiah Terhadap Harga Saham, Skripsi, Jakarta, Perbanas Institute.

Bodie, Kane, Marcus. 2006. Investasi Buku 2. Terjemahan Zuliani Dalimunthe dan Budi Wibowo. Jakarta : Salemba Empat.

Darmadji, Tjiptono, dan Fakhruddin (2012), Pasar Modal di Indonesia, Edisi Ketiga, Jakarta, Penerbit Salemba Empat.

Deitiana. 2011. Pengaruh Rasio Keuangan, Pertumbuhan Penjualan Dan Deviden Terhadap Harga Saham. Jurnal Bisnis Dan Akuntansi Vol 13, No.1, Hal 5766, April 2011.

Hugida, L., Sofian, S. 2011. Analisis FaktorFaktor Yang Mempengaruhi Volatilitas Harga Saham (Studi Pada Perusahaan Yang Terdaftar Dalam Indeks LQ45 Periode 2006-2009). Skripsi, Universitas Diponegoro.

Ina Rinati. 2010. Pengaruh Net Profit Margin (NPM), Return On Assets (ROA) Dan Return On Equity (ROE) Terhadap Harga Saham Pada Perusahaan Yang Tercantum Dalam Indeks LQ45, Skripsi. Fakultas Ekonomi, Universitas Gunadarma

Kristal Hykaj. 2015. Analysis Of Problematics Related To The Stock Market In Albania. European Scientific Journal. Vol 11. No.34

Kurniawati, Siska Indah, Amalia Rizkl. 2014. Pengaruh Luas Pengungkapan Sukarela dalam Laporan Tahunan Terhadap Return dan Harga Saham, Skripsi. Fakultas Ekonomi, Universitas Airlangga.

Lira Sihaloho. 2013. Pengaruh Inflasi, Suku Bunga dan Book Value (BV) terhadap Harga Saham Perusahaan Indeks LQ 45 yang Terdaftar Di Bursa Efek Indonesia (BEI). Skripsi. Fakultas Ekonomi Universitas Negeri Semarang. 
Mishkin, Frederic S. 2008. Ekonomi Uang, Perbankan, dan Pasar Keuangan. Edisi Sembilan, jilid 2. Jakarta: Salemba Empat.

Napitupulu, V., Syahyunan, S. 2013. Pengaruh Return Saham, Volume Perdagangan Dan Volatilitas Harga Saham Terhadap Bid-Ask Spread Pada Perusahaan Yang Melakukan Stock Split Di Bursa Efek Indonesia. Jurnal Media Informasi Manajemen.

Paul, Muthucattu Thomas, Yih Pin Tang, Markand Bhatt. 2011. A Study Of The Relation Between Inflation And Exchange Rates In The Fiji Islands: A Cointegration And Vector Error Correction Approach, The Journal of Developing Areas, Volume 48, No.4. University of the South Pacific, Fiji.

Ross, S.A, 1976. The determination of financial structure: The incentivesignalling approach, Bell Journal of economics, 8, 23-40.

Sarkar Humayun, Kabir, Omar K M R Bashar, A. Mansur M. Masih. 2014. Stock Price Evidence From Malaysia .The Journal of Developing Areas. Volume 48. No.3.

Sunariyah. 2011. Pengantar Pengetahuan Pasar Modal. Edisi 5. Yogyakarta: UPP STIM YKPN.

Suramaya Suci Kewal. 2012. Pengaruh Inflasi, Suku Bunga, Kurs, Dan Pertumbuhan PDB Terhadap Indeks Harga Saham Gabungan. Jurnal Economia,Volume 8, Nomor 1, April 2012.

Syed Shafqat, Abbas,Dr. Rehana Kouser,Muhammad Azeem.2013. Reexamining The Relationship Of Earnings And EquityWith Share Price: A Study Of Company Specific And Uncontrollable Dynamics In Pakistan, Journals Sci,Int(Lahore),25(4),927935, B. Z. University, Multan-Pakistan

Tandelilin, E. 2010. Portofolio dan Investasi: Teori dan Aplikasi. Edisi 1. Yogyakarta: Kanisius.
Thobarry, A. A. 2009. Analisis Pengaruh Nilai Tukar, Suku Bunga, Laju Inflasi dan Pertumbuhan GDP Terhadap Indeks Harga Saham Sektor Properti (Kajian Empiris pada Bursa Efek Indonesia Periode Pengamatan Tahun 20002008). Tesis, Universitas Diponegoro.

Ucok Saut, Timbul, Widyo Nugroho. 2009. Analisis Pengaruh EVA,ROA, ROE Dan Persentase Kepemilikan Modal Saham Asing Terhadap Harga Saham Perbankan Di BEI. Artikel, Universitas Gunadarma.

Yogi Permana. 2009. Pengaruh Fundamental Keuangan, Tingkat Bunga Dan Tingkat Inflasi Terhadap Pergerakan Harga Saham. Jurnal Akuntansi. Universitas Gunadarma.

Yogi Permana. 2009. Pengaruh Fundamental Keuangan, Tingkat Bunga Dan Tingkat Inflasi Terhadap Pergerakan Harga Saham. Jurnal Akuntansi. Universitas Gunadarma.

Kasmir (2013), Analisis Laporan Keuangan, Jakarta, Penerbit Rajawali Pers.

Kartika Shintia Dewi (2012), Analisa Pengaruh ROA, NPM, DER, dan Size Terhadap Praktik Perataan Laba, Skripsi, Semarang, Universitas Diponegoro.

Skousen, Stice (2009), Akutansi Keuangan Menengah, Edisi Kesembilan, Jilid Satu

Keown, Arthur J dkk (2010), Dasar-Dasar Manajemen Keuangan, Jakarta, Penerbit Salemba Empat.

Murni, Asfa 2011. Ekonomi Makro. Bandung : Refika Aditama

Ika Yunita dan Al Amin (2016), Rasio Keuangan dan Makro Ekonomi Terhadap Harga Saham, Magelang, Universitas Muhammadiyah.

Sofi dan Yahya (2016), Pengaruh Kinerja Keuangan Terhadap Harga Saham, Jurnal, Surabaya, Sekolah Tinggi Ilmu Ekonomi Indonesia (STIESIA).

Mankiw, N. G, Quah, E., \& Wilson, P. (2012), Principles of Economics (6th ed.), 
South Western, Pengantar Ekonomi Makro (Vol. II). (B. B. Alkemis, Trans.), Jakarta, Penerbit, Salemba Empat.

Edhi Asmirantho (2016), Pengaruh Kinerja Keuangan dan Variabel Makroekonomi Terhadap Return Saham Pada Subsektor Makanan dan Minuman Periode 2011-2015, Jurnal Akuntansi Vol.1 No. 2, p. 4.

Asrianti dan Syamsuri (2015), Pengaruh Laba dan Arus Kas Terhadap Harga Saham Perusahaan LQ45 di Bursa Efek Indonesia, Makassar, Universitas Muslim Indonesia.
Syed Shafqat, Abbas,Dr. Rehana Kouser,Muhammad Azeem.2013. Reexamining The Relationship of Earnings And EquityWith Share Price: A Study Of Company Specific And Uncontrollable Dynamics In Pakistan, Journals Sci,Int(Lahore),25(4),927935, B. Z. University, Multan-Pakistan

www.bi.go.id www.bps.go.id www.finance.yahoo.com

www.idx.co.id

\section{LAMPIRAN}

Lampiran 1. Hasil Statistik Deskriptif

Descriptive Statistics

\begin{tabular}{|l|r|r|r|r|r|}
\hline & $\mathrm{N}$ & Minimum & Maximum & \multicolumn{1}{c|}{ Mean } & $\begin{array}{c}\text { Std. } \\
\text { Deviation }\end{array}$ \\
\hline ROA & 35 & 1,90 & 31,20 & 10,6171 & 7,44614 \\
DER & 35 & 18,32 & 170,63 & 88,5134 & 43,73147 \\
AKB & 35 & 6,49 & 13,96 & 11,3073 & 2,23512 \\
INFLASI & 35 & 3,02 & 8,38 & 5,4820 & 2,43018 \\
NILAITUKAR & 35 & 9670,00 & 13795,00 & 12306,0000 & 1468,48395 \\
SUKUBUNGA & 35 & 5,75 & 7,75 & 7,0000 &, 76936 \\
V.HARGASAHA & 35 & 333,00 & 7925,00 & 2865,9714 & 2364,71036 \\
M & & & & & \\
Valid N & 35 & & & & \\
(listwise) & & & & & \\
\hline
\end{tabular}

Sumber: Data diolah oleh SPSS 22 
Lampiran 2. Hasil Uji Normalitas

One-Sample Kolmogorov-Smirnov Test

\begin{tabular}{|ll|r|}
\hline & & \multicolumn{2}{|c|}{ Unstandardized Residual } \\
\hline $\mathrm{N}$ & & 35 \\
Normal Parameters & Mean &, 0000000 \\
& Std. Deviation & 2058,64724724 \\
Most Extreme & Absolute &, 140 \\
Differences & Positive &, 140 \\
& Negative &,- 091 \\
Test Statistic & &, 140 \\
Asymp. Sig. (2-tailed) & &, $082^{\mathrm{c}}$ \\
\hline
\end{tabular}

a. Test distribution is Normal.

b. Calculated from data.

c. Lilliefors Significance Correction.

Sumber: Data diolah oleh SPSS 22

Lampiran 3. Hasil Uji Multikolonieritas

Coefficients $^{\mathrm{a}}$

\begin{tabular}{|c|c|c|c|c|c|c|c|c|}
\hline \multirow{2}{*}{\multicolumn{2}{|c|}{ Model }} & \multicolumn{2}{|c|}{$\begin{array}{c}\text { Unstandardized } \\
\text { Coefficients }\end{array}$} & \multirow{2}{*}{$\begin{array}{c}\begin{array}{c}\text { Standardize } \\
d\end{array} \\
\text { Coefficients } \\
\text { Beta }\end{array}$} & \multirow[b]{2}{*}{$\mathrm{t}$} & \multirow[b]{2}{*}{ Sig. } & \multicolumn{2}{|c|}{$\begin{array}{r}\text { Collinearity } \\
\text { Statistics } \\
\end{array}$} \\
\hline & & B & Std. Error & & & & $\begin{array}{c}\text { Toleranc } \\
\mathrm{e}\end{array}$ & VIF \\
\hline \multicolumn{2}{|c|}{1 (Constant) } & 2759,657 & 4973,258 & &,- 555 & ,583 & & \\
\hline & ROA & 152,591 & 84,749 & ,480 & $\begin{array}{r}1,80 \\
0\end{array}$ & ,083 & ,380 & 2,631 \\
\hline & DER & 1,360 & 14,511 & ,025 & 094 & 926 - l & 376 & 2,661 \\
\hline & AKB & 86,054 & 175,460 & 081 & 490 & 628 & 984 & 1,016 \\
\hline & INFLASI & 248,998 & 372,189 & ,256 & ,669 & ,509 & 185 & 5,405 \\
\hline & NILAITUKAR & 444 & 660 & 276 & 673 & ,506 & 161 161 & 6,207 \\
\hline & SUKUBUNGA & $-559,987$ & 1519,739 &,- 182 &,- 368 & 715 & 111 & 9,032 \\
\hline
\end{tabular}

Sumber: Data diolah oleh SPSS 22

JIAFE (Jurnal Ilmiah Akuntansi Fakultas Ekonomi)

Volume 3 No. 1 Tahun 2017, Hal. 35-48 
Lampiran 4. Hasil Uji Heteroskedastisitas

Scatterplot

Dependent Variable: HARGASAHAM

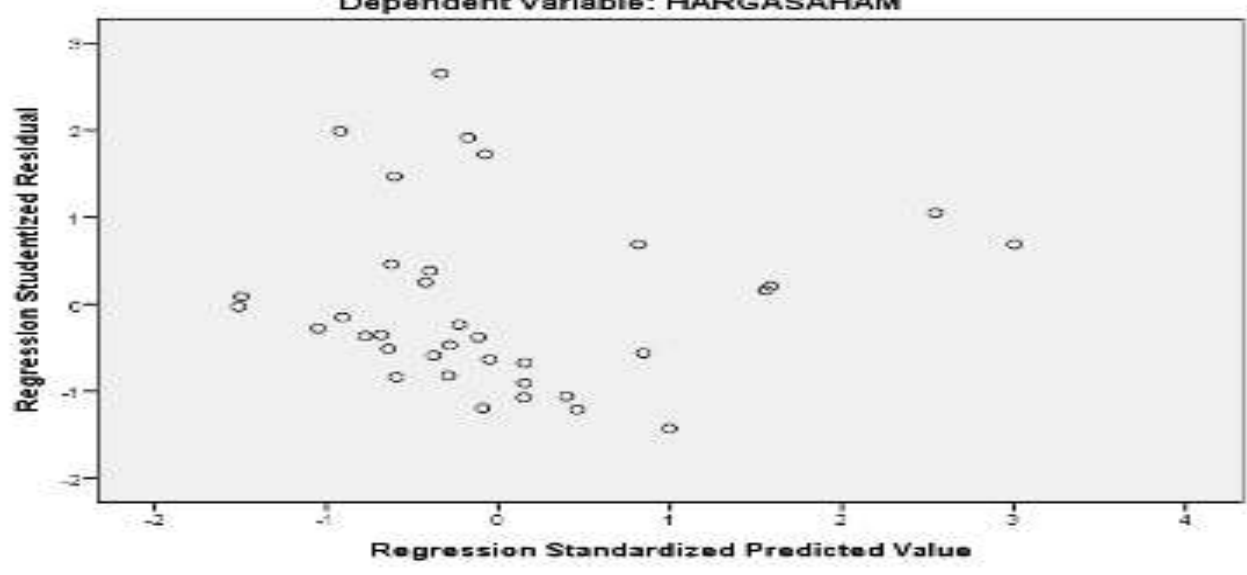

Sumber: Data diolah oleh SPSS 22

Lampiran 5. Hasil Uji Autokorelasi

Runs Test

\begin{tabular}{|l|r|}
\hline & Unstandardized Residual \\
\hline Test Value $^{\mathrm{a}}$ & $-565,41238$ \\
Cases $<$ Test Value & 17 \\
Cases $>=$ Test Value & 18 \\
Total Cases & 35 \\
Number of Runs & 14 \\
Z & $-1,369$ \\
Asymp. Sig. (2-tailed) &, 171 \\
\hline
\end{tabular}

a. Median

Sumber: Data diolah oleh SPSS 22

Lampiran6. Hasil Uji t

Coefficients $^{\mathrm{a}}$

\begin{tabular}{|ll|r|r|r|}
\hline \multicolumn{1}{|c|}{ Model } & \multicolumn{1}{c|}{ T } & \multicolumn{1}{c|}{ Sig. } & Keterangan \\
\hline 1 & (Constant) &,- 555 &, 583 & Tidak Berpengaruh \\
& ROA & 1,800 &, 083 & Tidak Berpengaruh \\
& DER &, 094 &, 926 & Tidak Berpengaruh \\
& AKB &, 490 &, 628 & Tidak Berpengaruh \\
& INFLASI &, 669 &, 509 & Tidak Berpengaruh \\
& NILAITUKAR &, 673 &, 506 & Tidak Berpengaruh \\
& SUKUBUNGA &,- 368 &, 715 & Tidak Berpengaruh \\
\hline
\end{tabular}

Sumber: Data diolah oleh SPSS 22 